\title{
Component reuse in structural design: emerging practices and tools for the circular economy
}

\section{Jan Brütting, Patrick Ole Ohlbrock, Pierluigi D'Acunto, Jonas Warmuth,} Corentin Fivet

jan.bruetting@epfl.ch,ohlbrock@arch.ethz.ch,pierluigi.dacunto@tum.de, jonas.warmuth@epfl.ch, corentin.fivet@epfl.ch

Link to the video: https://youtu.be/VCyD1yqXH8w
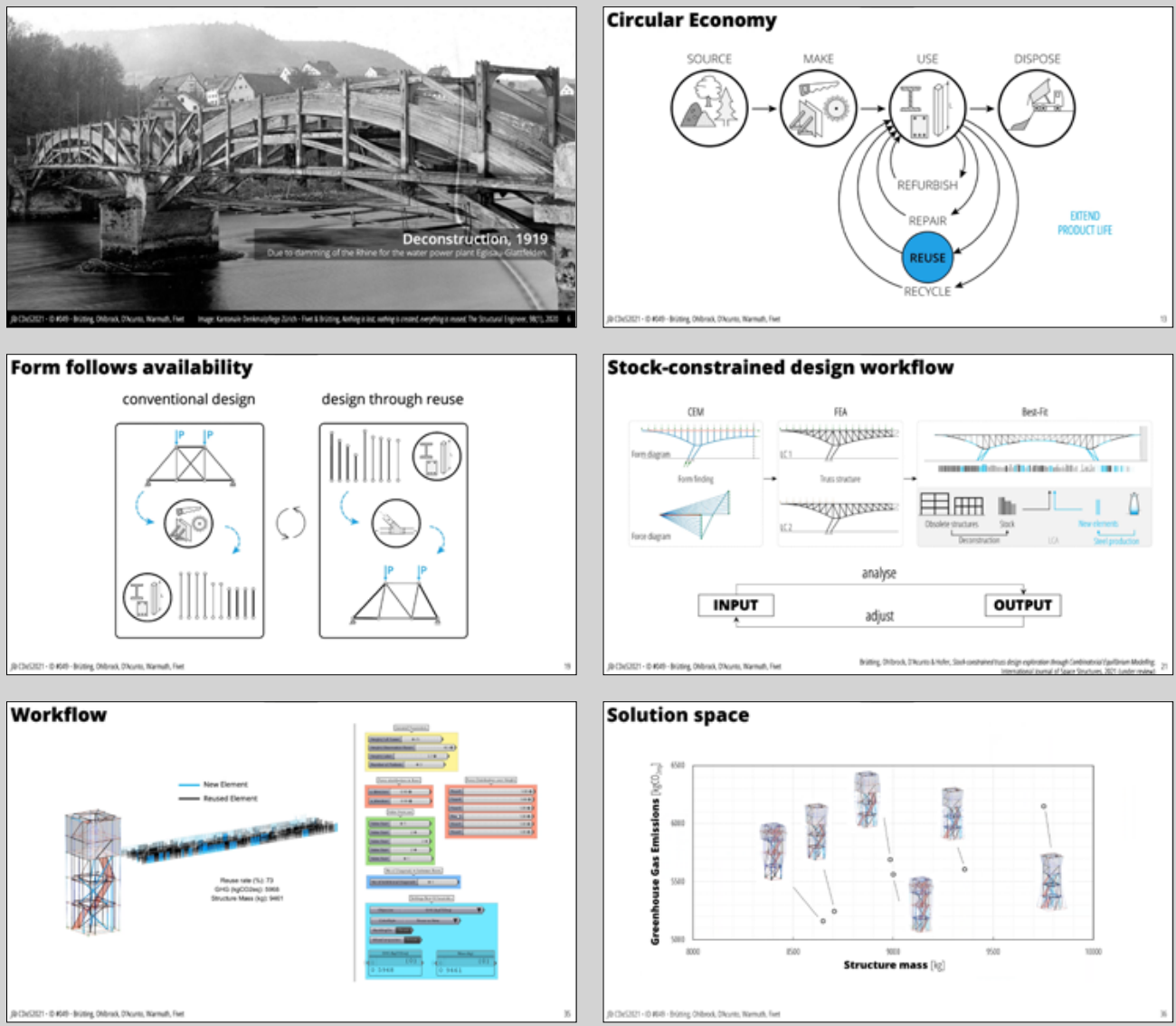